\title{
Marketing communication in beer industry in the Czech Republic with respect to minibreweries
}

\author{
Monika Březinová*, Zbyněk Havelka, Petr Bartoš \\ University of South Bohemia in České Budějovice, Faculty of Agriculture, Studentská 1668, 37005 \\ *Corresponding author: brezina@zf.jcu.cz
}

\begin{abstract}
Minibreweries are a specific group on the Czech beer market and they communicate with their customers mostly via their product - the beer. Their main asset is uniqueness and locality. Presentation of these breweries is mostly realized by financially less difficult methods. The present text deals with the problems of marketing communication of minibreweries with respect to the techniques used. Data collection was performed via electronic questionnaire in January 2017. researched sample consisted of 350 minibreweries as of 31 st December 2016. Recoverability of the questionnaires was $41 \%$ (145 minibreweries). The aim of the research was to find out, with the help of descriptive statistic methods, which marketing tools are used by minibreweries. The results confirm that, for marketing communication, minibreweries use mostly low-cost techniques such as own web pages, which are used by $90 \%$ of the researched minibreweries, social sites by $84 \%$ of respondents, and through the renown of the minibrewery by $80 \%$ of respondents. Furthermore there are tools to be used to differentiate the product, such as labels (in $90 \%$ of respondents), glasses and beer coasters (in $85 \%$ of respondents), the least used kind of these tools being the advertisement in the national broadcast transmission (in $4 \%$ of respondents) and in the news (in $8 \%$ of respondents).
\end{abstract}

Key words: minibreweries, marketing communication, beer, beer market

\section{Introduction}

There is a new form of breweries being currently established on the Czech beer market - the minibreweries. The number of these minibreweries has considerably increased not only in the Czech Republic (Colen and Swinnen, 2016). By the 31st December 2016, there were 350 minibreweries existing on the Czech beer market. Some of them had already established a strong position on the market and gradually increase their production, activities, and number of employees. Other minibreweries do not try to increase production, either because of the length of their existence or due to the purpose of their foundation.

According to the results of the research there are two reasons to establish minibreweries (Cabras and Higgins, 2016). The first reason is the pure passion for beer and the effort to produce it according to one's own requirements for taste and quality that are given mostly by the number of unwanted substances in beer. According to Běláková et al. (2017), unwanted substances were found within $83 \%$ of samples, though in a negligible amount. The other reason is business. The field of minibreweries is attractive for investors who notice a significant boom in this branch, just like other markets that grow fast (more than 10\% annually). Deliberations on what options, related to the building of the name on the market and using the marketing communication tools and leading to establishing minibreweries either of pure passion or as part of a business plan, are the keystone of the present text.

Marketing communication is a term that covers all aspects of visual, written, spoken and sensory interaction between a company and the target market (Cooper and Lane, 1999). This communication has mostly commercial character and its aim, based on the information that is on hand, is to influence cognitive and decision-marking processes of those who we want to impress and to meet our intentions (Vysekalová and Komárková, 2002). Marketing communication in "SME" has its restrictions that are given by the size of the company and the restrictions resulting from this fact, such as lack of financial and/or human resources. Some theories (Schmid, 2014) present information on experience-based restrictions.

For a systematic division of the broad scale of marketing communication techniques and tools, it is possible to use such theoretical supports as the 4P, adopted by Kottler and Amstrong (2003), the communication mix where the author includes advertisement, direct scale, personal sale, PR, and sale support, or the Pelsmacker et al. (2003) communication mix which includes advertisement, sale support, sponsorship, public relations, communication in the place where the sale takes place, exhibitions, direct marketing communication, personal sale, and interactive marketing. The above mentioned techniques and tools are all employed in the field of beer 


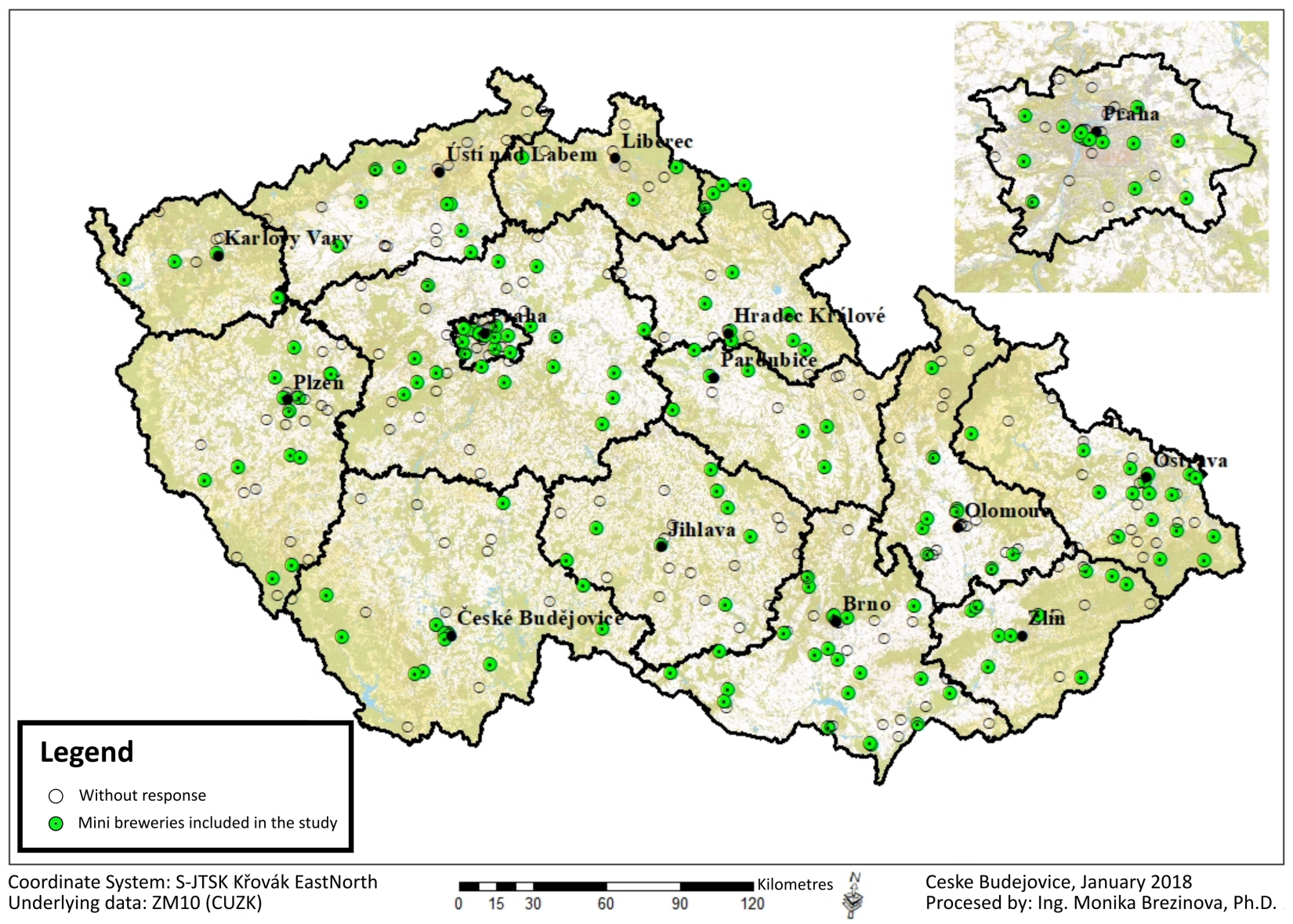

Figure 1: The map of minibreweries that generate the examined sample

market, but their use always depends on a particular situation. One of the most significant factors that influence the composition of the marketing communication mix is the size of the brewery, more specifically its financial power, and, furthermore the specifics of the customer segment that is served by the brewery (Castiglione et al., 2011).

From that point of view, marketing communication can be divided into two kinds of targeting. The first is mass communication, using its specific tools and aiming at the biggest possible number of potential customers - this kind of communication is used by industrial breweries.

The other kind is a targeted communication that uses personal communication channels and aims at a specific group of customers. The latter is used by minibreweries. In 2015, industrial breweries, realizing very expensive TV advertisement, noticed on average a $5 \%$ decrease of production. In 2016 the decrease was another 10\% (this decrease can probably be caused by an increasing number of minibreweries). On the other hand, some regional breweries significantly lowered resources for standard communication yet they increased the production. The Svijany brewery chose the method of "word of mouth", and doubled the production (Kozák and Kozáková. 2004).
Minibreweries are new on the Czech beer market and communicate with their customers mainly by their product - the beer. Their main asset is uniqueness ad locality (Toro-Gonzáles et al., 2014). Their presentation is then provided mainly by the word-of-mouth technique, i.e. orally, by satisfied visitors and fans of uncommon beers, who spread the word (Stoklásek, 2013). This phenomenon has another overlap for minibreweries since the same strategy applies in wine tourism (Cortese et al., 2017) and beer tourism (DudaGromada, 2013; Kraftchick et al., 2014).

As mentioned above, the most important factor for minibreweries that influences the choice of marketing tools, is finances (George, 2013). For this reason, there is no use of mass communication tools and channels (these assets would be more than ineffective with respect to the target group for minibreweries), but the breweries use personal targeted marketing channels such as regional news, social media, and other techniques that are more appropriate and cheaper in addressing regional or even local markets (in beer jargon there is a term for this "around the stack").

A very frequently used method is membership in organizations that put minibreweries together such as Association of minibreweries, Club of minibreweries, CzechMoravian association of minibreweries, and others. 


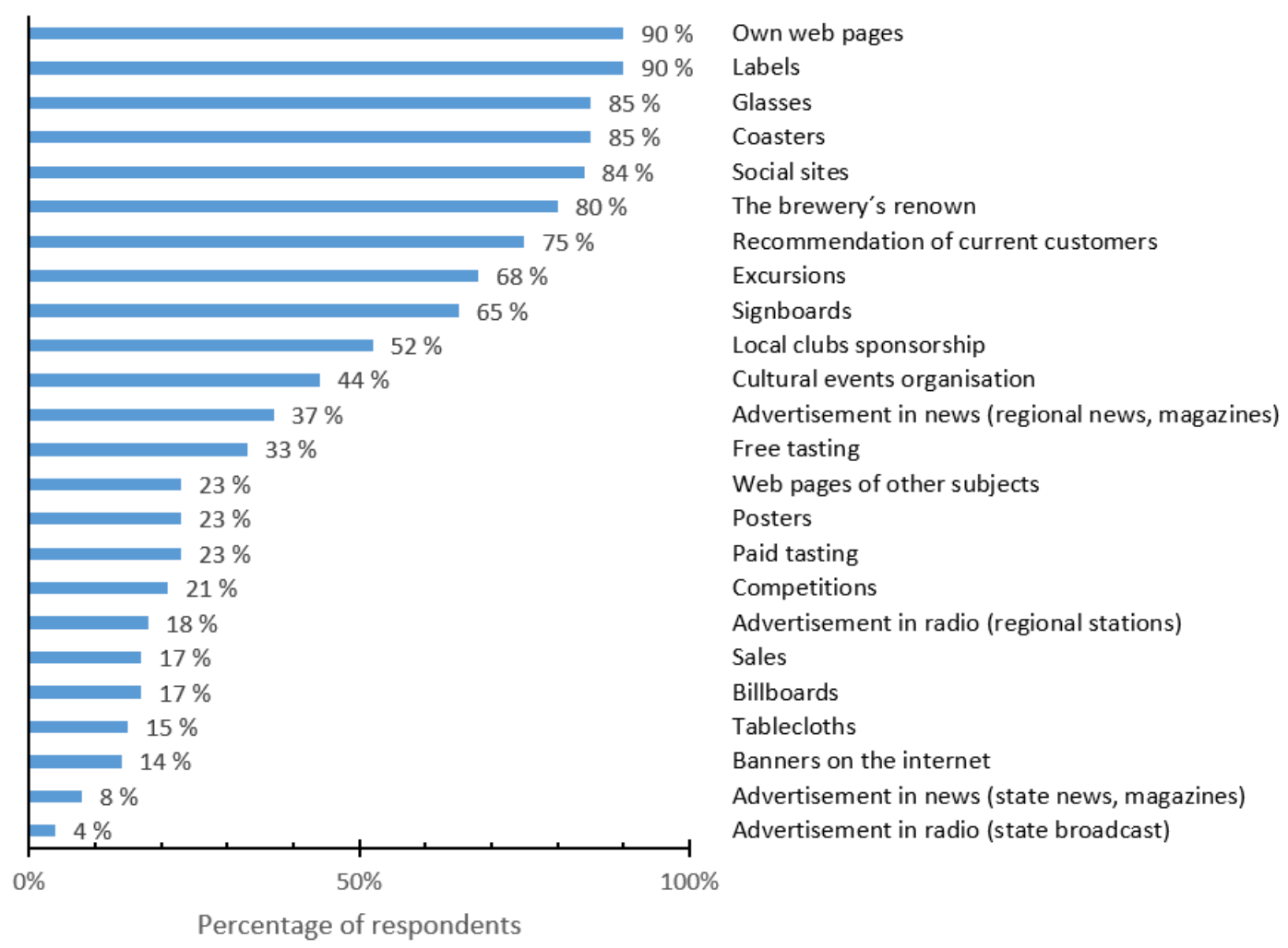

Figure 2: Marketing communication tools used by minibreweries

These organizations organize mutual meetings and events and, in this way, they spread general knowledge about mini breweries among the customers. They also contribute to the increase of interest in their products (Kozák and Kozáková, 2013).

\section{Methods}

This work is based on quantitative research methods. The method of electronic questionnaire survey used in it was chosen from among quantitative methods for the whole research sample in January 2017. Use was also made of descriptive statistics (absolute frequency, pivot tables), graphical and tabular visualisation of received results. During the processing of the gathered data, the results were divided according to segmentation criteria: year of foundation of the minibrewery, place of business (in the town, on the town periphery, out of the town), and the existence of the brewery's own facility (yes/no). The examined sample represents $41 \%$ (145 minibreweries) of the researched sample. Figure 1 shows minibreweries that generate the examined sample. Favourite tools, used by more than $50 \%$ of minibreweries, are educational excursions, sponsorship by local clubs and signboards. On the contrary, less than $30 \%$ of minibreweries use web pages of other subjects and posters $(22 \%)$, sales, billboards, tablecloths $(15 \%)$, advertisement banners on the internet, state broadcast advertisement (4\%), regional broadcast advertisement $(18 \%)$, advertisement in news $(8 \%)$, contests $(21 \%)$ and paid tasting $(23 \%)$.

As mentioned above, none of the minibreweries in the examined group use either state or regional TV stations. More specific results are presented in Figures 2 and 3 and Tables 1 and 2, where the results follow segmentation criteria, the brewery's year of foundation, existence of the brewery's own facility and the information on being situated in the respective country. The results in the field of marketing tools used by minibreweries in the Czech Republic are presented according to these segmentation criteria. The results divided according to the year of foundation show that all minibreweries included in the examined sample, founded before 2000, use labels, coasters, glasses with logo, signboards, own web pages, sales (in other two groups, this tool is used only by $10 \%$ of respondents) and the renown of the brewery. On the contrary, none of the respondents in this group uses tablecloths (despite the fact that this group contains even minibreweries with their own facility), advertisement in regional broadcast and on web pages of other subjects. All minibreweries founded between 2001 and 2010 use own web pages as well. Furthermore, $90 \%$ of this group use labels, coasters, glasses with logo, and recommendation of current customers. The use of other tools is documented in Table 2. 
Table1: Tools of marketing communication of minibreweries divided according to year of foundation

\begin{tabular}{|l|r|r|r|}
\hline \multirow{2}{*}{ Marketing communication tool } & \multicolumn{2}{|c|}{ Percentage of respondents } \\
\cline { 2 - 4 } & $\begin{array}{r}\text { Before } \\
\mathbf{2 0 0 0}\end{array}$ & $\begin{array}{c}\text { 2001- } \\
\mathbf{2 0 1 0}\end{array}$ & $\begin{array}{c}\text { 2011- } \\
\text { present }\end{array}$ \\
\hline Advertisement in news (regional news, magazines) & $33 \%$ & $45 \%$ & $35 \%$ \\
\hline Advertisement in news (state news, magazines) & $33 \%$ & $18 \%$ & $3 \%$ \\
\hline Advertisement in radio (regional stations) & $0 \%$ & $27 \%$ & $16 \%$ \\
\hline Advertisement in radio (state broadcast) & $33 \%$ & $0 \%$ & $3 \%$ \\
\hline Banners on the internet & $67 \%$ & $27 \%$ & $5 \%$ \\
\hline Billboards & $33 \%$ & $27 \%$ & $11 \%$ \\
\hline The brewery's renown & $100 \%$ & $82 \%$ & $81 \%$ \\
\hline Coasters & $100 \%$ & $91 \%$ & $84 \%$ \\
\hline Competitions & $67 \%$ & $45 \%$ & $11 \%$ \\
\hline Cultural events organisation & $33 \%$ & $64 \%$ & $41 \%$ \\
\hline Excursions & $67 \%$ & $64 \%$ & $70 \%$ \\
\hline Free tasting & $33 \%$ & $45 \%$ & $30 \%$ \\
\hline Glasses & $100 \%$ & $91 \%$ & $84 \%$ \\
\hline Labels & $100 \%$ & $91 \%$ & $92 \%$ \\
\hline Local clubs sponsorship & $67 \%$ & $55 \%$ & $51 \%$ \\
\hline Own web pages & $100 \%$ & $100 \%$ & $89 \%$ \\
\hline Paid tasting & $33 \%$ & $45 \%$ & $16 \%$ \\
\hline Posters & $33 \%$ & $27 \%$ & $22 \%$ \\
\hline Recommendation of current customers & $0 \%$ & $91 \%$ & $78 \%$ \\
\hline Sales & $100 \%$ & $9 \%$ & $11 \%$ \\
\hline Signboards & $100 \%$ & $73 \%$ & $62 \%$ \\
\hline Social sites & $67 \%$ & $82 \%$ & $89 \%$ \\
\hline Tablecloths & $0 \%$ & $9 \%$ & $19 \%$ \\
\hline Web pages of other subjects & 0 & $36 \%$ & $22 \%$ \\
\hline
\end{tabular}

An important fact within this group is that they use cultural events and free or paid tasting more often than the other two groups. The last group of minibreweries was founded between 2011 and 2016. Here $89 \%$ representatives of this group use social sites to share information about the minibrewery (the highest score in all three groups) and the same number of minibreweries have their own web pages (in other two groups, the total number is $100 \%$ ). Furthermore, this is the leading group regarding the number of excursions organized (70\%). Unlike all previous groups, they use all studied tools of marketing communication.

In the division of minibreweries according to their placement, all the minibreweries from the examined sample that are outside the town/village use coasters, glasses, signboards, recommendation of current customers and the renown of the brewery. On the other hand, they use very little tablecloths, contests, banners on the internet, billboards, sales, and state broadcast advertisement. All the minibreweries from the examined sample that are on the periphery of the town/village use their own web pages, $95 \%$ of them use social sites, labels, and coasters. As the least used tools stand again the state and regional broadcasts and state news. The minibreweries that are in the centre of towns or on the town periphery use the marketing tools give-and-take in the same way. The group that uses the chosen marketing tools in the largest measure is however the one that includes minibreweries located outside of towns/villages.

Almost all minibreweries from the examined sample, whether having/not having their own facilities, have their own web pages. Those minibreweries which have their own establishment own web pages in $90 \%$. These establishments do not use either advertisement in radio or posters and, logically, not even tablecloths which are, by the way, used only by $23 \%$ of the representatives of this group. Based on the above mentioned segmentation criteria, significant differences in the use of chosen marketing tools were found for example at "recommendation of current customers" where this tool is not used by minibreweries founded before 2000; in the other groups $91 \%$ or $78 \%$ minibreweries use this tool. Another conclusion is that chosen marketing tools are more used by minibreweries with their own facility. The only two tools used by more minibreweries without own facility were their own web pages and free tastings.

In the division according to the location of the minibrewery, the first place in the use of selected marketing tools is that for those located outside the town/village. In all, $100 \%$ of representatives use 6 chosen tools (labels, coasters, glasses, signboards, recommendation of current customers, and renown of the brewery). 
Table2: Tools of marketing communication of minibreweries division according to the place of business

\begin{tabular}{|c|c|c|c|}
\hline \multirow[b]{2}{*}{ Marketing communication tool } & \multicolumn{3}{|c|}{ Percentage of respondents } \\
\hline & $\begin{array}{c}\text { the center of a } \\
\text { town/village }\end{array}$ & $\begin{array}{c}\text { periphery of a } \\
\text { town/village }\end{array}$ & $\begin{array}{c}\begin{array}{c}\text { outside a } \\
\text { town/village }\end{array} \\
\end{array}$ \\
\hline Advertisement in news (regional news, magazines) & $40 \%$ & $55 \%$ & $24 \%$ \\
\hline Advertisement in news (state news, magazines) & $20 \%$ & $5 \%$ & $8 \%$ \\
\hline Advertisement in radio (regional stations) & $60 \%$ & $5 \%$ & $20 \%$ \\
\hline Advertisement in radio (state broadcast) & $0 \%$ & $5 \%$ & $4 \%$ \\
\hline Banners on the internet & $0 \%$ & $5 \%$ & $24 \%$ \\
\hline Billboards & $0 \%$ & $20 \%$ & $16 \%$ \\
\hline The brewery's renown & $100 \%$ & $85 \%$ & $80 \%$ \\
\hline Coasters & $100 \%$ & $80 \%$ & $92 \%$ \\
\hline Competitions & $0 \%$ & $35 \%$ & $16 \%$ \\
\hline Cultural events organisation & $40 \%$ & $40 \%$ & $52 \%$ \\
\hline Excursions & $80 \%$ & $75 \%$ & $64 \%$ \\
\hline Free tasting & $60 \%$ & $30 \%$ & $32 \%$ \\
\hline Glasses & $100 \%$ & $90 \%$ & $84 \%$ \\
\hline Labels & $100 \%$ & $95 \%$ & $92 \%$ \\
\hline Local clubs sponsorship & $40 \%$ & $50 \%$ & $60 \%$ \\
\hline Own web pages & $80 \%$ & $100 \%$ & $92 \%$ \\
\hline Paid tasting & $60 \%$ & $20 \%$ & $20 \%$ \\
\hline Posters & $20 \%$ & $25 \%$ & $24 \%$ \\
\hline Recommendation of current customers & $100 \%$ & $85 \%$ & $68 \%$ \\
\hline Sales & $0 \%$ & $15 \%$ & $20 \%$ \\
\hline Signboards & $100 \%$ & $70 \%$ & $60 \%$ \\
\hline Social sites & $80 \%$ & $95 \%$ & $84 \%$ \\
\hline Tablecloths & $0 \%$ & $10 \%$ & $24 \%$ \\
\hline Web pages of other subjects & $20 \%$ & $25 \%$ & $24 \%$ \\
\hline
\end{tabular}

The overall results can be interpreted in the way that most of the marketing tools are used by those minibreweries which are located out of town/village, have their own facility and were founded before 2000. Almost all minibreweries from the examined sample, whether having/not having their own facilities, have their own web pages. Those minibreweries which have their own establishment own web pages in $90 \%$. These establishments do not use either advertisement in radio or posters and, logically, not even tablecloths which are, by the way, used only by $23 \%$ of the representatives of this group.

Based on the above mentioned segmentation criteria, significant differences in the use of chosen marketing tools were found for example at "recommendation of current customers" where this tool is not used by minibreweries founded before 2000; in the other groups $91 \%$ or $78 \%$ minibreweries use this tool. Another conclusion is that chosen marketing tools are more used by minibreweries with their own facility. The only two tools used by more minibreweries without own facility were their own web pages and free tastings. In the division according to the location of the minibrewery, the first place in the use of selected marketing tools is that for those located outside the town/village. In all, 100\% of representatives use 6 chosen tools (labels, coasters, glasses, signboards, recommendation of current custo- mers, and renown of the brewery). The overall results can be interpreted in the way that most of the marketing tools are used by those minibreweries which are located out of town/village, have their own facility and were founded before 2000 .

\section{Conclusion}

With an increasing number of minibreweries in the Czech Republic, also the importance of marketing communication, with respect to the competitiveness and to the addressing of the target group increases. It can thus be recommended to minibreweries to focus more on "lowcost" marketing tools as it is done today, i.e. as mentioned above. They are as follows: recommendation of current customers and the renown of the brewery, presentation of minibreweries on the internet, social sites and own web pages, marketing tools on the place of business, glasses, labels, and coasters. In connection with a further development in this segment, it is necessary for minibreweries to be prepared for increased costs, linked with marketing communication, resulting from their increasing marketing effort as a tool of strengthening their competitiveness due to an increasing competition pressure. Despite that, a significant increase of consumers of minibreweries 
Advertisement in news (regional news, magazines)

Advertisement in news (state news, magazines)

Advertisement in radio (regional stations)

Advertisement in radio (state broadcast)

Banners on the internet

Billboards

The brewery's renown

Coasters

Competitions

Cultural events organisation

Excursions

Free tasting

Glasses

Labels

Local clubs sponsorship

Own web pages

Paid tasting

Posters

Recommendation of current customers

Sales

Signboards

Social sites

Tablecloths

Web pages of other subjects

- Mini breweries with own facility

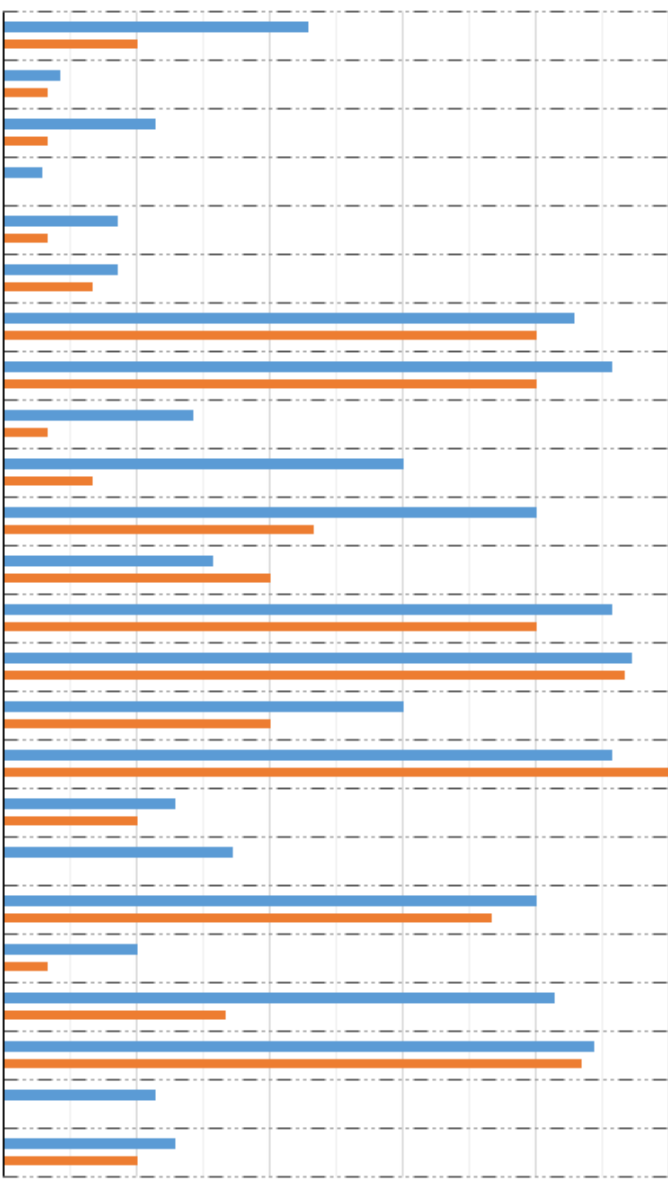

$0 \%$

$20 \%$

$40 \%$

$60 \%$

$80 \%$

$100 \%$

Percentage of respondents

Mini breweries without own facility

Figure3: Tools of marketing communication of minibreweries, divided into minibreweries with their own facility, and minibreweries without facility

production can be observed not only in the Czech $\mathrm{Re}$ public but in the whole Europe (Carvalho et al., 2018) and in other world regions.

A common general effort of small and medium-sized companies in all branches to use less expensive tools of marketing communication can be found (Madleňák and Madleňáková, 2016; Santillan et al., 2015; Taiminen and Karjaluoto, 2015) when the results of this research are compared to another similar research,. Breweries in Slovakia, with their own facilities, use even their family atmosphere and new experiences related to beer and the surroundings where the beer is consumed as a marketing communication tool (Dudič et al., 2018).
A chance how to reduce competition pressure among minibreweries was realized in London where all breweries founded before 2012 were placed in a minimal distance of $2 \mathrm{~km}$ from one another. Currently this distance is $1 \mathrm{~km}$ and the so called "urban beer paths", where the distance between breweries is 10 to $15 \mathrm{mi}$ nutes at most, are counted with (Dennett and Page, 2017). 


\section{References}

Běláková, S., Wawroszová, S., Benešová, K., 2017: The Occurrence of Mycotoxins in Beer from Retail Shops. Kvasny prum., 63(6):293-297.

Cabras, I., Higgins, D. M. 2016. Beer, brewing, and business history. BUS HIST., 58(5):609-624.

Carvalho, N. B., Minim, L. A., Nascimento, M., Ferreira, G. H. C., minim, V. P. R., 2018: Characterization of the consumer market and motivations for the consumption of craft beer. $\mathrm{Br}$. Food J., 120(2):378-391.

Castiglione, C., Grochová, L., Infante, D., Smirnova, J., 2011 The demand for beer in presence of past consumption and advertising in the Czech Republic. AGRICECON, 57(12):589-599.

Cooper, J., Lane, P., 1999: Marketingové plánování - praktická př́ručka manažera. Praha: Grada Publishing. ISBN 80-7169-6412

Colen, L., Swinnen, J., 2016: Economic Growth, Globalisation and Beer Consumption. J. Agric. Econ., 67(1):186-207.

Cortese, D., Pairotti, M. B., Giachino, C., Bonadonna, A., 2017: The art of craft beer in a traditional wine nation: a preliminary study in a model area. Quality - Access to Success, 18(161):149156

Dennett, A., Page, S., 2017: The Geography of London's Recent Beer Brewing Revolution. Geogr J, 183(4):440-454.

Duda-Gromada, K., 2013: Beer tourism in Poland. Pr. Stud. Geogr., 52:63-84

Dudič, B., Dudič, Z., Smolen, J., Mrkvová, K., Mirkovic, V., 2018: Beer and beer industry in Slovakia. Economics of Agriculture, 65(1):349-354.

George, L. M., 2013: National Television and the Market for Local Products: The Case of Beer. J Ind Econ, 57(1):85-111.
Kotler, P., Armstrong, G., 2003: Marketing. Praha: Grada Publishing. ISBN 978-80-247-0513-2.

Kozák, V., Kozáková, V., 2013: Změny v českém pivovarnictví na přelomu tisíciletí. Zlín: VeRBuM, ISBN: 978-80-87500-40-X.

Kozák, V., Kozáková, V., 2014: Televizní reklamy českých pivovarů a jejich vnímání. Zlín: VeRBuM, ISBN: 978-80-87500-45-3. Kraftchick, J. F., Byrd, E. T., Canziani, B., Gladwell, N. J. 2014: Understanding beer tourist motivation. Tourism Management Perspectives, 12:41-47.

Madleňák, R., Madleňáková, L., 2016: The global Impact of Emarketing Strategies SME in the Segment of Touristic Services. In 16th International Scientific Conference on Globalization and its Socio-Economic Consequences. Rajecke Teplice, Slovakia. pp. 1235-1243.

Pelsmacker, P., Geunes, M., Bergh, J. V., 2003: Marketingová komunikace. Praha: Grada Publishing. 584 pp. ISBN: 8024702541

Santillan, L., Luis, G., Medrano, F., 2015: Social Networks an Alternative to Marketing in SMEs. Revista Publicando. 2(4):111121.

Schmid, S., 2014: The Global Brewery Industry, Markets, Strategies, and Rivalries. J Int Manag, 20(4):478-480.

Stoklásek, J., 2013: Marketing a propagace pivovaru Zlínský Švec. Bachelor thesis. UTB in Zlín.

Taiminen, H. M., Karjaluoto, H., 2015: The usage of digital marketing channels in SMEs. J Small Bus Enterprise Dev, 22(4):633-651.

Toro-Gonzáles, D., McCluskey, J. J., Mittelhammer, R. C., 2014: Beer Snobs Do Exist: Estimation of Beer Demand by Type. J Agr Resour Econ, 39(2):174-187.

Vysekalová, J., Komárková, R., 2002: Psychologické reklamy: 2. rozširrené a aktualizované vydání. Praha: Grada Publishing, ISBN 80-247-0402-1. 